\title{
Повторна реваскуляризація рецидиву хронічної артеріальної недостатності після реконструкції аорто/клубово-стегнового сегмента
}

\begin{abstract}
Мета роботи: покращити результати повторної реваскуляризації артеріального русла нижніх кінцівок у хворих із рецидивом хронічної артеріальної недостатності шляхом застосування в комплексі повторного оперативного втручання методів ендоваскулярної ангіопластики.

Матеріали і методи. В роботу включено 522 пацієнти з атеросклеротичним ураженням аорто-стегно-підколінного сегмента. У 231 пацієнта діагностовано ХАН IIIA ст., у 191 - ХКІНК ІІІБ-IV ст., у 100 - ХАН ІІБ ст. Виділено три групи хворих. I група - 22 спостереження (28,2 \%) - первинна операція - реконструкція аорто/клубово-стегнової зони за відсутності гемодинамічно значущого атеросклеротичного процесу стегно-дистального сегмента; II група - 43 спостереження (55,1 \%) первинна операція - реконструкція аорто/клубово-стегнового сегмента за наявності стенотично-оклюзивного процесу стегнопідколінної зони; III група - 13 спостережень (16,7 \%) - первинна операція - реконструкція аорто/клубово-стегнової зони доповнена автовенозним стегно-дистальним шунтуванням.

Результати досліджень та їх обговорення. Повторну реваскуляризацію магістрального русла нижніх кінцівок при рецидиві ХАН здійснювали із врахуванням особливостей первинного оперативного втручання, локалізації стенотично-оклюзивного процесу, його поширеності та поєднання з іншими сегментами артеріального русла нижніх кінцівок. Виявлено прогресуюче ураження атеросклеротичним процесом зони дистального анастомозу аорто/клубово-стегнового алопротеза у 36 (48,7 \%) спостереженнях, а гомілкової зони - у 61 (78,2 \%) хворого. Основним хірургічним втручанням при повторній реваскуляризації були стегно-дистальні шунтуючі операції, які в 32 випадках доповнені ендоваскулярною балонною ангіопластикою гомілковоі артерії, з них у 19-ти втручаннях виконано ангіопластику одразу двох артерій. При оклюзивно-стенотичному процесі гомілкових артерій виконано 23 підколінно-задньо-великогомілкових (передньо-великогомілкових) шунтувань. Післяопераційний період у 10 (12,8 \%) пацієнтів ускладнився розвитком тромбозу сегмента реконструкції, з них у двох випадках після ендоваскулярної балонної ангіопластики.
\end{abstract}

Ключові слова: облітеруючий атеросклероз; повторна реваскуляризація; ускладнення реконструктивних втручань.

Постановка проблеми і аналіз останніх досліджень та публікацій. Реконструктивні операції при атеросклеротичних стенотично-оклюзивних ураженнях магістральних артерій нижніх кінцівок супроводжуються розвитком як у ранніх, так і віддалених післяопераційних ускладнень [1, 2, 4]. Ускладнення пізнього поопераційного періоду діагностують у 7,9 - 34,1 \% пацієнтів [3, 7]. Основною причиною розвитку пізніх ускладнень після реконструктивних втручань на магістральних судинах нижніх кінцівок вважається прогресування некорегованого атеросклеротичного процесу $[7,10]$. До найбільш частих ускладнень віддаленого післяопераційного періоду відносять тромбози артерій та шунтів, несправжні аневризми анастомозів, рецидив хронічної артеріальної недостатності [6, 5]. Наведені ускладнення пізнього поопераційного періоду вимагають проведення оперативного лікування $[8,9]$. Поряд із вказаним, повторні реконструкції артеріального русла нижніх кінцівок супроводжуються розвитком високого рівня ранніх післяопераційних ускладнень, серед яких тромбоз сегмента повторної реконструкції зустрічається найчастіше [12, 14].

Мета роботи: покращити результати повторної реваскуляризації артеріального русла ниж- ніх кінцівок у хворих із рецидивом хронічної артеріальної недостатності шляхом застосування в комплексі повторного оперативного втручання методів ендоваскулярної ангіопластики.

Матеріали і методи. Прослідковано протягом 2006 - 2019 рр. віддалені результати хірургічного лікування 522 пацієнтів, з яких 358 хворі із двобічною атеросклеротичною оклюзією аорто-стегнової зони та 164 із однобічною оклюзією клубово-стегнового сегмента. У 354 (67,8 \%) з них було порушення кровотоку по стегно-дистальній артеріальній зоні. На час первинного хірургічного втручання у 231 пацієнтів діагностовано ХАН IIIA ст. (за класифікацією Fontaine R. з врахуванням критеріїв Європейської робочої групи (1992)), у 191 - ХКІНК ІІІБ-ІV ст., у 100 - ХАН ІІБ ст..

У віддаленому післяопераційному періоді діагностовано 146 (27,97 \%) пізніх ускладнень, з яких у 78 (56,1 \%) виявлено рецидив хронічної артеріальної недостатності нижніх кінцівок. У 36 пацієнтів виявлено ХАН ІІБ ст., а у 42 - ХАН ІІІА ст. (за класифікацією Fontaine R. з врахуванням критеріїв Європейської робочої групи (1992)). Хворі повторно оперовані через $(5,4 \pm 1,9)$ року після пер- 
винної реваскуляризації аорто/клубово-стегнової (А/K-С) артеріальної зони. Всі чоловіки віком $(64,4 \pm 3,1)$ року.

Строки формування рецидиву ХАН у віддаленому поопераційному періоді у пацієнтів із багаторівневою реконструкцією магістрального артеріального русла на 2,8 року коротші, ніж у пацієнтів без порушення кровотоку по стегнодистальному артеріальному руслі і реваскуляризацією тільки аорто/клубово-стегнової зони.

При аналізі первинних оперативних втручань у пацієнтів із рецидивом ХАН виділено три групи хворих. При розподілі враховано багатоповерховість атеросклеротичного ураження магістрального русла нижніх кінцівок та об'єм первинної реконструкції аорто/клубово-стегново-підколінної артеріальної зони. I група - 22 спостереження (28,2 \%) - первинна операція - реконструкція аорто/клубово-стегнової зони за відсутності гемодинамічно значущого атеросклеротичного процесу стегно-дистального сегмента; II група - 43 спостереження (55,1 \%) - первинна операція - реконструкція аорто/клубово-стегнового сегмента за наявності стенотично-оклюзивного процесу стегно-підколінної зони; III група - 13 спостережень (16,7 \%) - первинна операція - реконструкція аорто/клубово-стегнової зони доповнена автовенозним стегно-дистальним шунтуванням.

Пацієнти із рецидивом ХАН у віддаленому післяопераційному періоді після реконструкції аорто/клубово-стегнової зони при госпіталізації пройшли ультрасонографічне та томографічне із ангілогічним підсиленням обстеження (комп’ютерний томограф Philips Brilliance 64, УЗД-апарат Philips HD-11XE).

Причиною рецидиву ХАН у пацієнтів I групи був: критичний стеноз дистального анастомозу із втягненням у процес глибокої артерії стегна (ГАС) (стеноз гирла 50 - 65 \%), стенотично-оклюзивний процес поверхневої артерії стегна (ПАС) - 7 спостережень; стенотично-оклюзивний процес ПАС і проксимального анастомозу (ПА) - 10 та стенотично-оклюзивний процес гомілкових артерій у 5 пацієнтів; гемодинамічно незначущий стенозуючий процес стегно-підколінного сегмента та стенотично-оклюзивний процес гомілкових артерій - 5 спостереження.

Рецидив ХАН у пацієнтів II групи зумовило стенозування дистального анастомозу A/K-C протеза із стенозом гирла $(60-70$ \%) ГАС та стенотично-оклюзивний процес гомілкових артерій - 11 спостережень; критичне стенозування дистального анастомозу A/K-С протеза із стенозом гирла (55 70 \%) ГАС, поширення оклюзї̈ ПАС на ПА та сте- нотично-оклюзивний процес гомілкових артерій - 14 спостережень; поширення атеросклеротичної оклюзї̈ ПАС на ПА та стенотично-окюзивний процес гомілкових артерій - 13 спостережень; критичний стеноз ПАС і ПА та стенотично-оклюзивний процес гомілкових артерій - 5 спостережень.

У III групі пацієнтів причиною рецидиву ХАН були: несправжня аневризма дистального A/K-C анастомозу та оклюзія стегно-дистального автовенозного шунта - 1 спостереження; критичний стеноз дистального аорто/клубово-стегнового анастомозу із втягненням у процес гирла ГАС та оклюзія стегно-дистального автовенозного шунта (до колінної щілини - 3, нижче колінної щілини 1) - 4 спостереження; оклюзія стегно-дистального автовенозного шунта (до колінної щілини - 3, дистальний анастомоз із підколінною артерією 5) та стенотично-оклюзивний процес гомілкових артерій - 8 спостережень.

Результати досліджень та їх обговорення. Повторну реваскуляризацію магістрального русла нижніх кінцівок при рецидиву ХАН здійснювали iз врахуванням особливостей первинного оперативного втручання, локалізації стенотично-оклюзивного процесу, його поширення та поєднання 3 іншими сегментами артеріального русла нижніх кінцівок.

У пацієнтів I групи при критичному стенозі дистального анастомозу (ДА) А/K-С алопротеза із втягненням у процес ГАС (стеноз гирла 50 - 65 \%) і стенотично-оклюзивному процесі ПАС (7 спостережень) виконали повну резекцію ДА (2 спостереження), а у 5 обмежились виключенням ДА без повного його виділення із наступним алопротезуванням. При алопротезуванні проксимальний анастомоз формували із дистальним сегментом A/K-С алопротеза, а дистальний - кінець в бік на рівні нижньої третини ПАС. У всіх спостереженнях проводили формування анастомозу гирла ГАС із алопротезом.

У пацієнтів при стенотично-оклюзивному процесі ПАС та ПА (10 спостережень) і втягненні у процес гомілкового артеріального русла (5 спостереження) проведено стегно-дистальне алошунтування (6 спостережень), автовенозне шунтування (4 спостереження). Проксимальний анастомоз формували на рівні ДА А/K-C алопротеза, дистальний - із ПАС до щілини колінного суглоба (2 спостереження) і на рівні ПА (8 спостережень). В 5 випадках операції доповненні ендоваскулярною балонною ангіопластикою гомілкових артерій (у 3 випадках ендоваскулярна балонна ангіопластика двох артерій гомілки, в одному випадку 
ендоваскулярна балонна ангіопластика тібіоперинеального стовбура, в одному випадку ендоваскулярна балонна ангіопластика задньої великогомілкової артерії (ЗВГА)).

При гемодинамічно незначущому стенозі стегно-підколінного сегмента та стенотично-оклюзивному процесі гомілкових артерій (5 спостережень) у двох пацієнтів проведено підколінноЗВГА автовенозне шунтування, а у інших трьох виконано ендоваскулярну балонну ангіопластику (балонна ангіопластика тібіоперинеального стовбура і передню великогомілкову артерію (ПВГА) або ЗВГА - 2 спостереження, балонну ангіопластику ЗВГА - 1 спостереження ).

У пацієнтів II групи при критичному стенозуванні ДА А/К-С протеза із стенозом гирла ГАС (60 - $70 \%$ ) та стенотично-оклюзивному процесі гомілкових артерій (11 спостережень) проводили повну резекцію ДА (4 спостереження), а у 7 обмежились виключенням ДА без повного його виділення із наступним алопротезуванням. При алопротезуванні проксимальний анастомоз формували із дистальним сегментом A/K-C протеза, а дистальний - кінець в бік на рівні нижньої третини ПАС (4 випадків) та на рівні ПА (7 випадків). У всіх спостереженнях формували анастомоз гирла ГАС із алопротезом. У 5 спостереженнях здійснено підколінно-ЗВГА автовенозне шунтування, у 6 - ендоваскулярну балонну ангіопластику гомілкових артерій (у 4 випадках ендоваскулярну балонну ангіопластику двох артерії гомілки).

При критичному стенозуванні ДА А/K-C протеза із стенозом гирла ГАС (55 - 70 \%), поширенні оклюзії ПАС на ПА та стенотично-оклюзивному процесі гомілкових артерій (14 спостережень) обмежились виключенням ДА без повного його виділення із наступним алопротезуванням. При алопротезуванні проксимальний анастомоз формували із дистальним сегментом A/K-C протеза, а дистальний кінець анастомозували із ПА. У всіх спостереженнях здійснювали ендартеректомію із ПА і анастомозування ГАС у бік алопротеза. У 5 спостереженнях здійснено підколінно-ЗВГА автовенозне шунтування, в одному - підколінноПВГА автовенозне шунтування, у 8 - ендоваскулярну балонну ангіопластику гомілкових артерій (у 5 випадках ендоваскулярна балонна ангіопластика двох артерії гомілки, у одному спостереженні ендоваскулярна балонна ангіопластика тібіоперинеального стовбура і ПВГА, у 2 випадках ендоваскулярна балонна ангіопластика ЗВГА або ПВГА).

При поширенні атеросклеротичної оклюзії ПАС на ПА та стенотично-оклюзивному проце- сі гомілкових артерій (13 спостережень) здійснювали алопротезування, при якому проксимальний анастомоз формували із ДА А/К-С протеза, а дистальний - на рівні ПА. У всіх спостереженнях перед формуванням дистального анастомозу здійснювали ендартеректомію із ПА. У 4 спостереженнях проведено підколінно-ЗВГА автовенозне шунтування, у двох - підколінно-ПВГА автовенозне шунтування, у 7 - ендоваскулярну балонну ангіопластику гомілкових артерій (у 4 з них ендоваскулярна балонна ангіопластика по дві артерії гомілки).

При критичному стенозі ПАС і ПА та стенотично-оклюзивному процесі гомілкових артерій (5 випадків) здійснювали алопротезування (4 спостереження), автовенозне шунтування (1 спостереження), при якому проксимальний анастомоз формували із ДА А/K-С протеза, а дистальний на рівні ПА. Перед формуванням дистального анастомозу проводили ендартеректомію із ПА. У 2 спостереженнях здійснено підколінно-ЗВГА автовенозне шунтування, в одному - підколінноПВГА автовенозне шунтування, у 2 - ендоваскулярну балонну ангіопластику гомілкових артерій (у 2 випадках ендоваскулярна балонна ангіопластика двох артерії гомілки).

Серед пацієнтів III групи у віддаленому поопераційному періоді діагностовано несправжню аневризму дистального A/K-С анастомозу та оклюзію стегно-дистального автовенозного шунта (1 випадок). У наведеному спостереженні здійснено повну резекцію аневризми ДА А/K-C, відсічено ГАС на рівні її гирла. При алопротезуванні проксимальний анастомоз формували із дистальним сегментом A/K-C алопротеза за типом кінець у кінець, а дистальний - кінець алопротеза у бік ПА. Дистальну 1/3 частину алопротеза замінено автовеною. Відновлення кровобігу по ГАС здійснено шляхом вшивання гирла ГАС у бік алопротеза.

При критичному стенозі ДА А/K-С протеза із втягненням у процес гирла ГАС та оклюзії стегно-дистального автовенозного шунта (4 спостереження) виконали повну резекцію ДА (1 спостереження), а у 3 обмежились виключенням ДА без повного його виділення із наступним алопротезуванням. При реалопротезуванні проксимальний анастомоз формували за типом кінець алопротеза в бік дистального первинного анастомозу первинного алопротеза, а дистальний, при цьому дистальну 1/3 частину алопротеза замінено на автовену, - кінець реавтовени у бік ПА. Відновлення кровобігу по ГАС здійснювали шляхом анастомозування гирла ГАС у бік алопротеза (3 спостереження). 
При оклюзії стегно-дистального автовенозного шунта та стенотично-оклюзивному процесі гомілкових артерій (8 спостережень) здійснювали стегно-дистальне реавтовенозне шунтування (2 випадки), реалошунтування (один випадок), тромбектомію із автовенозного шунта із відновленням функції анастомозів (один проксимальний, 4 дистальні). Наведені оперативні втручання доповнювали: в одному спостереженні проведенням підколінно-ЗВГА автовенозним шунтування, у двох - підколінно-ПВГА автовенозним шунтуванням, у 3 - ендоваскулярною балонною ангіопластикою гомілкових артерій (у 2 випадках ендоваскулярна балонна ангіопластика двох артерії гомілки). У двох спостереженнях не було можливості здійснити реваскуляризуючу операцію і тому проведено РОТ.

Післяопераційний період у 10 (12,8 \%) пацієнтів ускладнився розвитком тромбозу сегмента реконструкції. Дігностовано тромбоз підколінноЗВГА (3 спостережння) автовенозного шунта, тромбоз підколінно-ПВГА (одно спостережння) автовенозного шунта. У двох спостереженнях тромбоз розвинувся після ендоваскулярної балонної ангіопластики гомілкових артерій. В одному випадку тромбоз стегно-дистального автовенозного шунта сформувався із-за компресії останнього на рівні підколінної ямки. В одному спостереженні розвинувся тромбоз стегно-дистального реалошунта, причиною якого був стеноз алошунта на рівні анастомозу його із гирлом ГАС.

У 7 наведених вище спостереженнях вдалось ліквідувати тромбоз сегмента реконструкції. В одному випадку спроби його ліквідувати були невдалими, подібне спостерігалось у випадку виконання балонної ангіопластики гомілкової артерії.

У двох спостереженнях функціонування реавтовенозного шунта була порушена із-за неможливості відновити прохідність шляхів відтоку - стенотично-оклюзивний процес гомілкових артерій (проведено реваскуляризуючу остеотрепанацію великогомілкової кістки). Тромбоз реавтовенозного шунта ліквідувати не вдалось.

Прогресування атеросклеротичного процесу основна причина набуття хронічної артеріальної недостатності у віддаленому періоді після реваскуляризації аорто/клубово-стегнової зони. Спостерігається системне ураження артеріальної системи, але особливою мішенню прогресування атеросклеротичного процесу є сегменти травматизації артеріального русла (анастомози, ендартеректомія) та гомілкова артеріальна зона. Так, у представленому дослідженні виявлено прогресуюче ураження атеросклеротичним процесом зони дистального анас- томозу А/K-С алопротеза у 36 (48,7 \%) спостереженнях, а гомілкової зони - у 61 (78,2 \%) хворого. Поєднання вказаних зон прогресування атеросклеротичного процесу формувало розвиток хронічної артеріальної недостатності і зумовлювало об’єм реваскуляризуючих операцій у пацієнтів із рецидивом хронічної артеріальної недостатності у віддаленому післяопераційному періоді після реконструкції аорто/клубово-стегнової зони.

В умовах критичного стенозу дистального анастомозу аорто/клубово-стегнового алопротеза із втягненням у процес ГАС у 7 спостереженнях виконали повну резекцію дистального анастомозу, а у 29 обмежились виключенням останнього без повного його виділення. Виключення дистального анастомозу без повного його виділення було застосовано у більшої частини повторно оперованих пацієнтів, це пов'язано із технічними труднощами проведення виділення дистального анастомозу аорто/клубово-стегнового алопротеза в рубцевих тканинах попереднього хірургічного втручання. Зону дистального анастомозу аорто/ клубово-стегнового протеза у пацієнтів із рецидивом хронічної артеріальної недостатності використовували при стегно-дистальному ало- або автовенозному шунтуванні.

Особливу увагу приділили шляхам відтоку артеріям гомілкової зони. При оклюзивно-стенотичному процесі гомілкових артерій виконано 23 підколінно-ЗВГА (ПВГА) шунтувань та 32 ендоваскулярні балонні ангіопластики гомілкових артерій. При цьому у 19 спостереженнях для збільшення об’єму артеріального русла гомілки здійснювали ендоваскулярну балонну ангіопластику двох артерій. Поряд із наведеним не вдалось уникнути в ранньому післяопераційному періоді розвитку тромбозу сегмента реконструкції. Тромбоз підколінно-ЗВГА автовенозного шунта діагностовано у 4 спостереженнях. В двох випадках тромбоз розвинувся після ендоваскулярної балонної ангіопластики гомілкових артерій, що у 2,8 раза рідше, ніж при підколінно-гомілкових шунтуваннях.

Висновки. Найпоширеним оперативним втручанням при повторній реваскуляризації в умовах рецидиву хронічної артеріальної недостатності $€$ стегно-дистальні ало- і автовенозні шунтування.

Ревакуляризацію гомілкового сегмента забезпечують стегно/підколінно-гомілкове автовенозне шунтування (23 спостереження) або методи ендоваскулярної ангіопластики (32 спостереження), які є складовими повторної реваскуляризації артеріального русла в умовах рецидиву хронічної артеріальної недостатності. 


\section{З ДОСВІДУ РОБОТИ}

\section{СПИСОК ЛІТЕРАТУРИ}

1. Кобза I. I. Повторні реконструкції з приводу інфікування синтетичних судинних протезів: вибір аутовенозного матеріалу/ І. І. Кобза, Р. А. Жук, Я. І. Ярема // Вісник невідкладної і відновної медицини. - 2010. - № 11. - С. 521-523.

2. Кобза I. І. Хірургічне лікування пацієнтів при інфікуванні судинних протезів аорто-стегнової зони / I. І. Кобза, Т. Г. Сорока, Р. А. Жук // Клінічна хірургія. - 2004. - № 4-5. - С. 89-90. 3. Губка В. А. Хирургическое лечение осложнений операций у больных облитерирующим атерослерозом аорты и артерий нижних конечностей / В. А. Губка // Патологія. - 2012. - № 1. - C. 89-91.

4. Повторні реконструктивні втручання на черевній частині аорти та периферичних артеріях / А. Б. Доміняк, Ю. Л. Ящук, Г. Г. Влайков, А. В. Ратушняк // Серце і судини. - 2005. - № 1. - С. 56-57.

5. Conte M. S. Critical appraisal of surgical revascularization for critical limbischemia / M. S. Conte // Journal of Vascular Surgery. - 2013. - Vol. 57. - P. 8S - 13S.

6. Диденко Ю. П. Причины выполнения повторных оперативных вмешательств в отдаленные сроки после реконструктивных операций на артериях нижних конечностей у больных с облитерирующим атеросклерозом / Ю. П. Диденко, Г. Н. Горбунов // Вестник Санкт-Петербургского университета. - Серия 1. - 2008. - Выпуск 1. - С. 71-76.

7. Results of infrapopliteal endovascular procedures performed in diabeticpatients with critical limb ischemia and tissue loss from the perspective of anangiosome-oriented revascularization strategy / F. Acun, C. Varela, I. Lopez de Maturana [et al.] // International Journal of Vascular Medicine. - 2014. - Vol 3. P. 1-13.

8. Белов Ю. В. Повторные реконструктивные операции на аорте и магистральных артериях / Ю. В. Белов, А. Б. Степа- ненко. - Москва : Мед. информ. агентство, 2009. - 174 с. 9. Русин В. І. Повторні реконструктивні операції при реоклюзії судин стегново-подколінно-тібіального сегмента / В. І. Русин, В. В. Корсак, Ю. А. Левчан // Клінічна хірургія. - 2004. - № 4-5. - С. 104-105.

10. Гощинський В. Б. Про ефективність різних методів ендоваскулярної реваскуляризації при хронічній ішемії нижніх кінцівок / В. Б. Гощинський, О. Б. Луговий, В. В. Ольховик // Шпитальна хірургія. Журнал імені Л. Я. Ковальчука. - 2015. - № 4. - С. 26-30.

11. Дзюба Д. О. Варіанти періопераційного знеболювання хворих із критичною ішемією нижніх кінцівок, що прооперовані методом ендоваскулярної балонопластики / Д. О. Дзюба, С. М. Недашківський, О. М. Злочевський // Медицина неотложных состояний: Специализированный научно-практический журнал. - 2016. - № 3. - С. 72-74.

12. Русин В. В. Гібридні операції з приводу критичної ішемії тканин нижніх кінцівок / В. В. Русин // Клінічна хірургія: науково-практичний журнал. - 2013. - № 9. - С. 42-46.

13. Femoropopliteal balloon angioplasty vs. bypass surgery for CLI: a propensityscore analysis / M. Korhonen, F. Biancari, M. Soderstrom [et al.] // Eur. J. Vasc. Endovasc. Surg. - 2011. Vol. 41, №3. - P. 378 - 384.

14. Гудз О. І. Можливості неінвазивної діагностики стану дистального артеріального русла у пацієнтів із хронічною критичною ішемією нижніх кінцівок / О. І. Гудз, І. М. Гудз // Серце і судини : Український науково-практичний журнал. 2012. - № 2. - С. 112-116.

15. Ендоваскулярні втручання при критичній ішемії нижніх кінцівок / В. І. Русин, В. В. Корсак, Я. М. Полович, В. В. Русин // Клінічна анатомія та оперативна хірургія : науково-практичний медичний журнал. - 2014. - Т. 13, № 2. - С. 66-68.

\section{REFERENCES}

1. Kobza, I.I., Zhuk, R.A., \& Yarema, Ya.I. (2010). Povtorni rekonstruktsii z pryvodu infikuvannia syntetychnykh sudynnykh proteziv: vybir autovenoznoho materialu [Repeated reconstructions for the infection of synthetic vascular prostheses: the choice of autogenous material]. Visnyk nevidkladnoi $i$ vidnovnoi medytsyny - Bulletin of Emergency and Restorative Medicine, 11, 521-523 [in Ukrainian].

2. Kobza I.I., Soroka T.H., \& Zhuk, R.A. (2004). Khirurhichne likuvannia patsiientiv pry infikuvanni sudynnykh proteziv aortostehnovoi zony [Surgical treatment of patients with infection of the aortic-femoral vascular prostheses]. Klinichna khirurhiia Clinical Surgery, 4-5, 89-90 [in Ukrainian].

3. Gubka, V.A. (2012). Khirurgicheskoe lechenye oslozhneniy operatsyy u bolnykh obliteryruyushchim ateroslerozom aorty i arteriuy nyzhnykh konechnostey [Surgical treatment of advanced operations in large forms of aortic atherosclerosis and lower extremity arteries]. Patolohiia - Pathology, 1, 89-91 [in Ukrainian].

4. Dominiak, A.B. Yashchuk, Yu.L., Vlaikov, H.H., \& Ratushniak, A.V. (2005). Povtorni rekonstruktyvni vtruchannia na cherevnii chastyni aorty ta peryferychnykh arteriiakh [Repeated reconstructive interventions on the abdominal aorta and peripheral arteries]. Sertse i sudyny - Heart and Blood Vessels, 1, 56-57 [in Ukrainian].

5. Conte, M.S. (2013). Critical appraisal of surgical revascularization for critical limb ischemia. Journal of Vascular Surgery, 57, 8-13.
6. Didenko, Yu.P., \& Gorbunov, G.N. (2008). Prichiny vypolneniya povtornykh operativnykh vmeshatelstv v otdalennye stroki posle rekonstruktivnykh operatsyy na arteriyakh nizhnikh konechnostey u bolnykh s obliteriruyushchim aterosklerozom [Reasons for performing repeat surgery in the long term after reconstructive surgery on the arteries of the lower extremities in patients with obliterating atherosclerosis]. Vestnik SanktPeterburgskogo universiteta - Bulletin of St. Petersburg University, 1 (1), 71-76 [in Russian].

7. Acun, F., Varela, C., \& Lopez de Maturana I. (2014). Results of infrapopliteal endovascular procedures performed in diabetic patients with critical limb ischemia and tissue loss from the perspective of an angiosome-oriented revascularization strategy. International Journal of Vascular Medicine, 3, 1-13.

8. Belov, Yu.V., \& Stepanenko, A.B. (2009). Povtornye rekonstruktivnye operatsyy na aorte i magistralnykh arteriyakh [Repeated reconstructive operations on the aorta and main arteries]. Moscow: Med. inform. agent. [in Russian].

9. Rusyn, V.I., Korsak, V.V., \& Levchan, Yu.A. (2004). Povtorni rekonstruktyvni operatsii pry reokliuzii sudyn stehnovo-podkolinnotibialnoho sehmenta [Repeated reconstructive operations at reocclusion of vessels of the femur-popliteal-tibial segment]. Klinichna khirurhiia-Clinical Surgery, 4-5, 104-105 [in Ukrainian]. 10. Hoshchynskyi, V.B., Luhovyi, O.B., \& Olkhovyk, V.V. (2015). Pro efektyvnist riznykh metodiv endovaskuliarnoi revaskuliaryzatsii pry khronichnii ishemii nyzhnikh kintsivok [About efficiency of different methods of endovascular slpiced at 
the chronic ischemia of lower extremities]. Shpytalna khirurhiia: Ukrainskyi naukovo-praktychnyi zhurnal - Hospital Surgery: Ukrainian Research and Practice Journal, 4, 26-30 [in Ukrainian]. 11. Dziuba, D.O., Nedashkivskyi, S.M., \& Zlochevskyi, O.M. (2016). Varianty perioperatsiinoho zneboliuvannia khvorykh iz krytychnoiu ishemiieiu nyzhnikh kintsivok, shcho prooperovani metodom endovaskuliarnoi balonoplastyky [Variants of the perioperating anaesthetizing of patients are with the critical ischemia of lower extremities which are operated by the method of endovascular operation]. Medytsyna nevidkladnykh staniv: Spetsializovanyi naukovo-praktychnyi zhurnal - Emergency Medicine: Specialized Scientific and Practical Journal, 3, 7274 [in Ukrainian].

12. Rusyn, V.V. (2013). Hibrydni operatsii z pryvodu krytychnoi ishemii tkanyn nyzhnikh kintsivok [Hybrid surgery for critical lower limb tissue ischemia]. Klinichna khirurhiia: Naukovopraktychnyi zhurnal - Clinical Surgery: A Scientific and Practical Journal, 9, 42-46 [in Ukrainian].
13. Korhonen, M., Biancari, F., \& Soderstrom M. (2011). Femoropopliteal balloon angioplasty vs. bypass surgery for CLI: a propensity score analysis. European Journal Vascular and Endovascular Surgery, 41 (3), 378-384.

14. Hudz, O.I., \& Hudz, I.M. (2012). Mozhlyvosti neinvazyvnoi diahnostyky stanu dystalnoho arterialnoho rusla u patsiientiv iz khronichnoiu krytychnoiu ishemiieiu nyzhnikh kintsivok [Possibilities of non-invasive diagnosis of distal arterial status in patients with chronic critical lower limb ischemia]. Sertse $i$ sudyny: Ukrainskyi naukovo-praktychnyi zhurnal - Heart and Blood Vessels: Ukrainian Scientific and Practical Journal, 2, 112-116 [in Ukrainian].

15. Rusyn, V.I. (2014). Endovaskuliarni vtruchannia pry krytychnii ishemii nyzhnikh kintsivok [Endovascular interventions for critical lower limb ischemia]. Klinichna anatomiia ta operatyvna khirurhiia: naukovo praktychnyi medychnyi zhurnal - Clinical Anatomy and Surgery: A Scientific Medical Journal, 13 (2), 6668 [in Ukrainian].

Отримано 30.09.2019

\section{REPEATED REVASCULARIZATION OF A CHRONIC ARTERIAL FAILURE RECURRENCE AFTER AORTOILIAC-FEMORAL SEGMENT RECONSTRUCTION}

The aim of the work: to improve results of revascularization of the lower extremity arterial bed in patients with relapse of chronic arterial insufficiency by applying endovascular angioplasty methods in the complex of re-operative surgery.

Materials and Methods. The results of surgical treatment of 522 patients with atherosclerotic occlusion of the aortoiliac-femoral segment mere studied. 231 patients were diagnosed with stage IIIA arterial insufficiency, 191 had chronic critical arterial ischemia stage IIIB-IV, and 100 had chronic stage IIB. In the analysis of primary surgical interventions, three groups of patients were identified in patients with recurrent chronic arterial ischemia. Group I included 22 observations (28.2 \%) - primary surgery - reconstruction of the aortoiliac-femoral area in the absence of hemodynamically significant atherosclerotic process of the femoral-distal segment, group II 43 observations (55.1\%) - primary surgery - reconstruction aortoiliac-femoral segment in the presence of stenotic-occlusive process of the femoral-popliteal zone. Group III - 13 observations (16.7 \%) - primary surgery - reconstruction of the aortoiliac-femoral area with autogenous femoral-distal bypass grafting.

Results and Discussion. Revascularization of the lower limb trunk at relapse of chronic arterial ischemia was performed taking into account the features of the primary surgical intervention, localization of the stenotic-occlusive process, prevalence and combination with other segments of the lower extremity arterial bed. Progressive lesions of the atherosclerotic process of the zone of distal anastomosis of the aortoiliac-femoral alloprosthesis were detected in 36 (48.7\%) observations, the tibia zone - in 61 (78.2 \%) patients. The main intervention at revascularization was femoral-distal shunting operations, which in 32 cases were supplemented with endovascular balloon angioplasty of the tibial artery, of which in 19 interventions angioplasty of two arteries was performed. In the occlusive-stenotic process of the tibial arteries, 23 popliteal-posterior-tibial (anterior-tibial) shunts were performed. The postoperative period in 10 (12.8\%) patients was complicated by the development of reconstruction segment thrombosis and in 2 cases the thrombosis developed after endovascular balloon angioplasty.

Key words: obliterating atherosclerosis; repeated revascularization; complications of reconstructive interventions. 


\author{
И. К. ВЕНГЕР, М. О. ГУСАК, Д. В. КОВАЛЬСКИЙ, С. Я. КОСТИВ, А. Р. ВАЙДА, Н. И. ГЕРАСИМЮК
}

Тернопольский национальный медицинский университет имени И. Я. Горбачевского МОЗ Украины

\title{
ПОВТОРНАЯ РЕВАСКУЛЯРИЗАЦИЯ РЕЦИДИВА ХРОНИЧЕСКОЙ АРТЕРИАЛЬНОЙ НЕДОСТАТОЧНОСТИ ПОСЛЕ РЕКОНСТРУКЦИИ АОРТО/ПОДВЗДОННО-БЕДРЕННОГО CEГMEHTA
}

Цель работы: улучшить результаты повторной реваскуляризации артериального русла нижних конечностей у больных с рецидивом хронической артериальной недостаточности путем применения в комплексе повторного оперативного вмешательства методов эндоваскулярной ангиопластики.

Материалы и методы. Прослежено отдаленные результаты хирургического лечения 522 пациентов с атеросклеротическим поражением аорто-бедренно-подколенного сегмента. У 231 пациентов диагностирован ХАН IIIA ст., по классификации Fontaine R. с учетом критериев Европейской рабочей группы, в 191 - ХКИНК IIIБ-IV ст., в 100 - ХАН ІІБ ст. Выделено три группы больных. I группа - 22 наблюдения (28,2 \%) - первичная операция - реконструкция аорто/подвздошно-бедренной зоны при отсутствии гемодинамически значимого атеросклеротического процесса бедренно-дистального сегмента, II группа - 43 наблюдения $(55,1$ \%) - первичная операция - реконструкция аорто/подвздошно-бедренного сегмента при наличии стенотичнооклюзионного процесса бедренно-подколенной зоны. III группа 13 наблюдений (16,7 \%) - первичная операция - реконструкция аорто/подвздошно-бедренной зоны дополненная аутовенозным бедренно-дистальным шунтированием.

Результаты исследований и их обсуждение. Повторную реваскуляризацию магистрального русла нижних конечностей при рецидиве ХАН осуществляли с учетом особенностей первичного оперативного вмешательства, локализации стенотично-оклюзионного процесса, его распространенности и сочетании с другими сегментами артериального русла нижних конечностей. Установлено прогрессирующее поражение атеросклеротическим процессом зоны дистального анастомоза аорто/подвздошнобедренного аллопротеза в 36 (48,7 \%) наблюдениях, а берцовой зоны - в 61 (78,2 \%) больного. Основным хирургическим вмешательством при повторной реваскуляризации были бедренно-дистальные шунтирующие операции, в 32 случаях дополненные эндоваскулярной баллонной ангиопластикой берцовой артерии, из них в 19-ти вмешательствах выполнено ангиопластику сразу двух артерий. При оклюзивно-стенотическом процессе берцовых артерий выполнено 23 подколенно-задне-большеберцовых (передне-большеберцовых) шунтирований. Послеоперационный период у 10 (12,8 \%) пациентов осложнился развитием тромбоза сегмента реконструкции, из них в двух случаях после эндоваскулярной баллонной ангиопластики.

Ключевые слова: облитерирующий атеросклероз; повторная реваскуляризация; осложнения реконструктивных вмешательств. 